\title{
Rice Disease caused by Ustilaginoidella graminicola.
}

\author{
BY
}

ED. ESSED, B.Sc. (Edin.).

\section{With Plate XXXI.}

$\mathrm{R}$ ICE has for a long time been cultivated in Guiana, but it seems R that nothing was known before of any disease destroying rice crops, until about a year ago, when a rather serious disease broke out among the rice fields. Care was bestowed on it by the staff of the experimental station, where it was investigated without the cause being found; at least in the annual report, I909, I read that neither the Government botanist nor the Agricultural instructor succeeded in finding the cause of the disease. I am well pleased to be able to communicate the positive results of my research.

The plants are often attacked in their most tender age, and then the whole crop may come to nothing, the haulms drying up long before the time of flowering ; or they may be taken hold of shortly before flowering or at the time of flowering, and then only a small percentage of the flowers may escape destruction. Many apparent fruits are found to be empty husks. The disease first manifests itself by dark-brown intercostal spots with yellowish margins appearing on the leaves and sometimes on the sheaths also (see Pl. XXXI, Fig. I). The general aspect is that of 'Rust'. Besides the rice, another grass, a species of Panicum, was found to be suffering from the same disease.

If a fragment of a leaf, having been stained with eosin and passed through alcohol of progressive strengths, carbol-xylol, and xylol, and at last enclosed in balsam, be brought under a low power, the dark spots will be seen to consist of a dark-brown centre-where the epidermis may be absorbed-gradually passing to a yellow periphery with indistinct lines of demarcation. Hyphae are seen to run through and between the epidermal cells, branching in all directions, entering and emerging from the stomata; spores of the same types as met with in the two foregoing species are found lying on the leaf, and crowded in and between the epidermal cells and in the emergences. The brown spots are nothing but pegmatia, cementing, as it were, the cells attacked and so rendering the cell-walls quite indistinct (see

[Annals of Botany, Vol. XXV. No. XCVIII. April, I9II.] 
Fig. 2). The prosenchyma and the wood vessels are only seized upon in a far advanced stage of the disease, when pegmatia and small chlamydospores of irregular shape and greenish brown colour may be seen to form within the vessels and sclereids.

Pure cultures were not easily obtained, on account of the overwhelming number of bacterial colonies overrunning the mycelia. But when the leaves were first rinsed under the tap for a long time, steeped in 90 per cent. alcohol for two minutes, and washed out again under the tap for some time so as to remove the alcohol, and at last dried in the stove at a temperature of $40^{\circ} \mathrm{C}$. for two days, the leaf fragments could be easily pounded into a coarse powder, which could be shaken with a sufficient quantity of sterilized water so as to obtain a suitable inoculation fluid. A few drops of the liquid, strained through a linen cloth previously steeped in boiling water, were poured on four Drigalsky plates and spread. The results were gratifying; two days after inoculation I was able to transfer nine pure growing mycelia.

Since the differences between this and the two foregoing Fungi are not very great, it will suffice to cite these differences, so avoiding unnecessary prolixity.

Pegmatia. Not differing; the chlamydosporangioid form smaller.

Spores. Chlamydospores smaller than in the two other species; colour greenish brown. Chlamydosporangia smaller, but of the same hue as in the two other species. Conidia I-5 celled, sickle shaped, rather larger than in the two other species. As typical for this fungus may be considered the I-, 3-, and 5-celled conidia, the 2- and 4-celled ones being scarce. Conidiophores as in Ust. oedipigera.

Haustoria, as in the last-named fungus.

Enzyme. The enzyme obtained in the ordinary way was only capable of gelatinizing the cell-walls; no proteolytic action was discovered.

Hyphal walls, as in Ust. oedipigera.

The results of the inoculation experiments will be mentioned later on.

\section{EXPLANATION OF FIGURES IN PLATE XXXI.}

Illustrating Mr. Ed. Essed's paper on Rice Disease.

Fig. I. Diseased spots in leaf. $\times 6$.

Fig. 2. Transverse section of leaf. $(A)$ pegmatia in parenchyma; $(B)$ spores in emergences and stoma. $\times 255$.

Fig. 3. (a) Fertile hyphae with conidia, chlamydospores, and pegmatia ; $(b)$ chain of oidia and chlamydospores. 
Annals of Botany - Vol.XXVI.PL.XXXI.

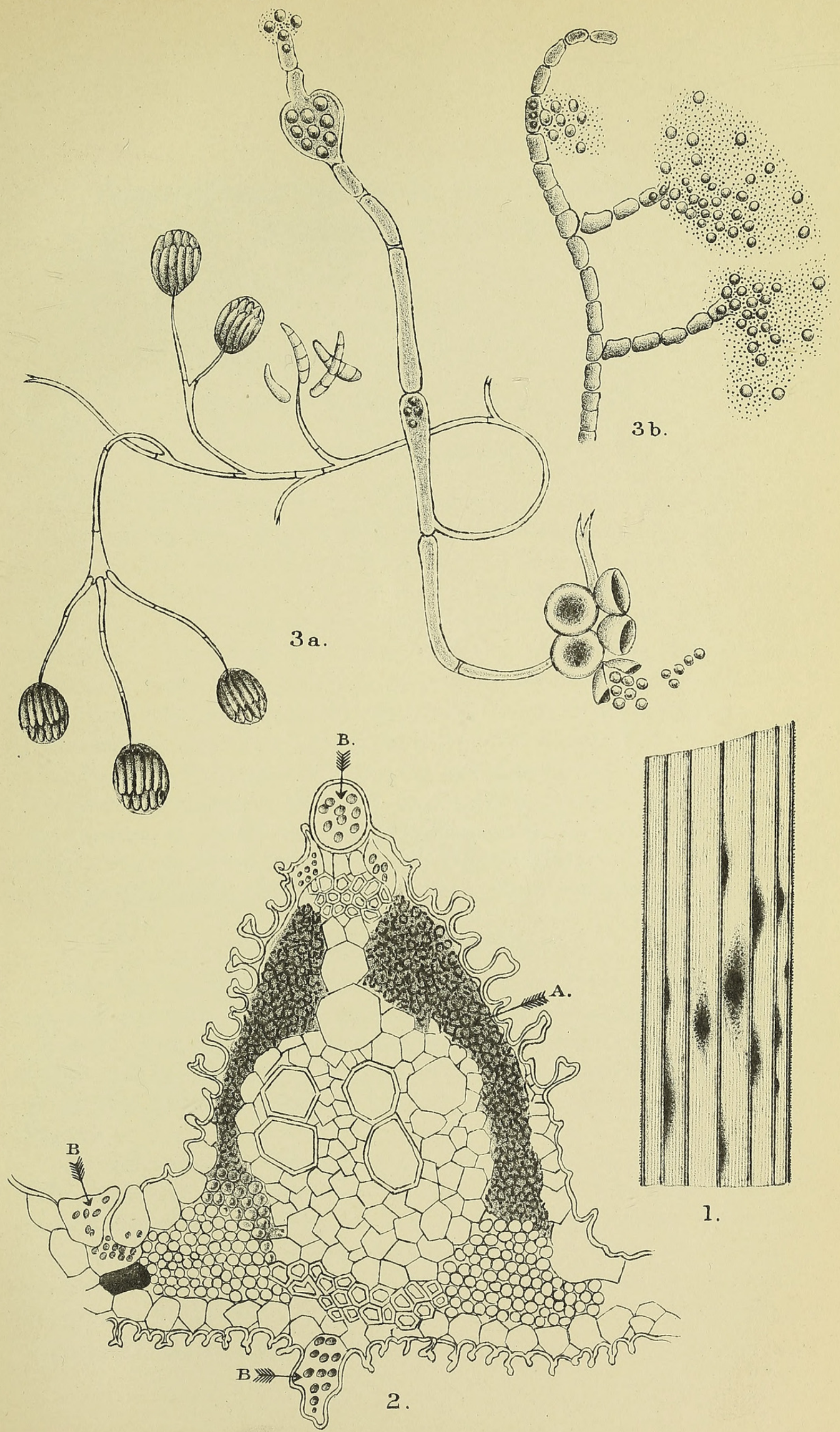




\section{$2 \mathrm{BHL}$ Biodiversity Heritage Library}

Essed, E. 1911. "Rice disease caused by Ustilaginoidella graminicola." Annals of botany 25, 367-368. https://doi.org/10.1093/oxfordjournals.aob.a089332.

View This Item Online: https://www.biodiversitylibrary.org/item/236971

DOI: https://doi.org/10.1093/oxfordjournals.aob.a089332

Permalink: https://www.biodiversitylibrary.org/partpdf/319840

\section{Holding Institution}

Smithsonian Libraries

\section{Sponsored by}

Biodiversity Heritage Library

\section{Copyright \& Reuse}

Copyright Status: Not in copyright. The BHL knows of no copyright restrictions on this item.

This document was created from content at the Biodiversity Heritage Library, the world's largest open access digital library for biodiversity literature and archives. Visit BHL at https://www.biodiversitylibrary.org. 